Aneta Rzepka ${ }^{1}$,Anna Mania ${ }^{2}$

\title{
THE CLINICAL PICTURE OF INFLUENZA AGAINST OTHER RESPIRATORY TRACT INFECTIONS IN A GENERAL PRACTITIONER PRACTICE
}

\section{OBRAZ KLINICZNY GRYPY NA TLE INNYCH ZAKAŻEŃ DRÓG ODDECHOWYCH W GABINECIE LEKARZA RODZINNEGO}

\author{
${ }^{1}$ Medicus Primary Health Care Centre, Magdalena Kurnatowska, ul. Starogostyńska 9, 63-800 Gostyń \\ Przychodnia Lekarza Podstawowej Opieki Zdrowotnej Medicus, Magdalena Kurnatowska, \\ ul. Starogostyńska 9, 63-800 Gostyń \\ ${ }^{2}$ Department of Infectious Diseases and Child Neurology, \\ Poznan University of Medical Sciences \\ Klinika Chorób Zakaźnych i Neurologii Dziecięcej, \\ Uniwersytet Medyczny im. K. Marcinkowskiego w Poznaniu
}

\begin{abstract}
INTRODUCTION. Influenza is an acute infectious disease caused by an RNA virus. In Poland, influenza occurs seasonally during the epidemic period lasting from October to April. The peak of influenza incidence in Poland falls in the first quarter of the year, with a comparable number of cases in January, February and March. Influenza can be severe in some patients, requiring hospitalization, or even fatal, especially in high-risk patients. OBJECTIVE. Analysis of the frequency and course of influenza in primary care patients compared to other respiratory tract infections.

MATERIAL AND METHODS. The study included a group of 631 adult patients with symptoms of respiratory infection who saw their GP (general practitioner) in the period from December 2018 to April 2020. Patients reporting symptoms of respiratory tract infection were included in the study. Special attention was paid to influenza-like symptoms, i.e. sudden onset fever and $\geq 1$ respiratory clinical symptom such as cough, sore throat, rhinitis or feeling of stuffy nose and $\geq 1$ systemic symptom such as headache, muscle pain, sweating or chills, fatigue persisting $<72 \mathrm{~h}$. Rapid antigen tests were performed in case of influenza-like symptoms. Influenza was diagnosed in patients with the above symptoms and a positive antigen test. In the study group, 356 rapid flu tests were performed. Age, comorbidities, nicotinism, vaccination status, clinical symptoms, ordered x-rays, laboratory tests, the result of the Actim Influenza A\&B rapid antigen test (Medix Biochemica) for influenza virus infection, and the final diagnosis were taken into account.

RESULTS. Influenza was diagnosed in 91 patients (in one person on the basis of clinical symptoms, without confirmation with a rapid antigen test), including 50 women and 41 men. The mean age of the patients was 47 years, the age range was 22-89 years. In 90 patients the infection with the influenza virus was confirmed with the Actim Influenza A\&B test (Medix Biochemica). One patient was diagnosed with influenza on the basis of typical clinical symptoms, despite a negative antigen test, and prior contact with a person with confirmed influenza.

Fever, cough, myalgia, tachypnoea, chest pain and reported respiratory disturbances, confirmed by abnormal results of physical examination, were more frequent in patients with symptoms of influenza and a positive antigen test than in other infections. Influenza was significantly more often observed in patients with impaired glucose tolerance, atherosclerosis, and muscle diseases. Influenza was mainly diagnosed in unvaccinated patients.
\end{abstract}

Key words: influenza, general practitioner, clinical picture

(c) National Institute of Public Health NIH - National Research Institute / Narodowy Instytut Zdrowia Publicznego PZH - Państwowy Instytut Badawczy 


\section{STRESZCZENIE}

WSTĘP. Grypa jest ostrą choroba zakaźną wywoływana przez wirus RNA. W Polsce grypa występuje sezonowo w okresie epidemicznym trwającym od października do kwietnia. Szczyt zachorowań na grypę w Polsce przypada na pierwszy kwartał roku, z porównywalną liczbą przypadków w styczniu, lutym i marcu. Grypa może mieć u niektórych pacjentów przebieg ciężki, wymagający hospitalizacji, a nawet śmiertelny, zwłaszcza w grupie pacjentów wysokiego ryzyka.

CEL. Analiza częstości występowania oraz przebiegu grypy u pacjentów podstawowej opieki zdrowotnej na tle innych zakażeń dróg oddechowych.

MATERIAŁ I METODY. Badaniem objęto grupę 631 dorosłych pacjentów z objawami infekcji dróg oddechowych, którzy zgłosili się do lekarza rodzinnego w okresie od grudnia 2018 do kwietnia 2020 roku. Do badania kwalifikowano pacjentów zgłaszających objawy infekcji dróg oddechowych. Zwracano szczególną uwagę na objawy przypominające grypę tj. gorączkę o nagłym początku oraz $\geq 1$ objaw kliniczny ze strony układu oddechowego, taki jak kaszel, ból gardła, nieżyt nosa lub uczycie zatkania nosa oraz $\geq 1$ objaw ogólnoustrojowy, taki jak ból głowy i mięśni, poty lub dreszcze, zmęczenie utrzymujące się $<72 \mathrm{~h}$. W przypadku występowania objawów przypominających grypę przeprowadzano szybki test antygenowy. U pacjentów z powyższymi objawami oraz dodatnim testem antygenowym rozpoznawano grypę.

W badanej grupie wykonano 356 szybkich testów w kierunku grypy. Uwzględniono wiek, występujące choroby współistniejące, nikotynizm, status szczepień, objawy kliniczne, zlecone badania radiologiczne, badania laboratoryjne, wynik szybkiego testu antygenowego Actim Influenza A\&B (Medix Biochemica) w kierunku zakażenia wirusem grypy, postawione rozpoznanie końcowe.

WYNIKI. Grypę rozpoznano u 91 pacjentów (u 1 osoby na podstawie objawów klinicznych, bez potwierdzenia szybkim testem antygenowym) w tym u 50 kobiet i 41 mężczyzn. Średnia wieku pacjentów to 47 lat, zakres wieku 22-89 lat. U 90 osób potwierdzono zakażenie wirusem grypy testem Actim Influenza A\&B (Medix Biochemica). U 1 pacjenta rozpoznano grypę na podstawie typowych objawów klinicznych oraz wcześniejszego kontaktu z osobą z potwierdzoną grypą pomimo ujemnego testu antygenowego.

U pacjentów z objawami grypy i dodatnim testem antygenowym częściej niż w przypadku pozostałych infekcji występowały gorączka, kaszel, bóle mięśniowe, tachypnoe, bóle w klatce piersiowej oraz zgłaszane zaburzenia oddychania, potwierdzane odchyleniami w badaniu przedmiotowym. Grypę istotnie częściej obserwowano u pacjentów z upośledzoną tolerancją glukozy, miażdżycą, chorobami mięśni. Grypę rozpoznawano głównie u pacjentów niezaszczepionych.

Słowa kluczowe: grypa, praktyka lekarza rodzinnego, obraz kliniczny

\section{INTRODUCTION}

Influenza is an acute infectious disease caused by an RNA virus from the Orthomyxoviridae family (1). Influenza viruses are classified into four types: A, B, $\mathrm{C}$, and D (2). Epidemic diseases in humans are caused by types A and B. Currently, seasonal influenza is most often caused by viruses of the $\mathrm{A} / \mathrm{H} 1 \mathrm{~N} 1 /$ pdm09 and A/H3N2 subtypes. Influenza A virus is characterized by its high antigenic variability, mainly due to an antigenic shift, which increases the risk of falling ill each year and the need for annual updating of vaccine compositions. The influenza season in the northern hemisphere is from autumn to early spring (October-April) (3). The peak of influenza incidence in Poland falls in the first quarter of the year. Almost half of the cases occur in children up to the age of 14 $(4,5)$. The influenza virus infects and then damages the epithelial cells of the nose, larynx, trachea and bronchi (6). Complications are associated with severe

\section{WSTĘP}

Grypa jest ostrą choroba zakaźną wywoływaną przez wirus RNA z rodziny Orthomyxoviridae (1). Wirusy grypy zaklasyfikowane są do czterech typów: A, B, C i D (2). Epidemiczne zachorowania u ludzi wywołują typy A i B. Grypę sezonową obecnie najczęściej wywołują wirusy podtypów A/H1N1/pdm09 i A/H3N2. Wirus grypy A charakteryzuje się dużą zmiennością antygenową, głównie na drodze przesunięcia antygenowego, które zwiększa ryzyko zachorowania każdego roku i konieczność corocznej aktualizacji składu szczepionek. Sezon zachorowań na grypę na półkuli północnej przypada na okres od jesieni do wczesnej wiosny (październik - kwiecień) (3). Szczyt zachorowań na grypę w Polsce przypada na pierwszy kwartał roku. Niemalże połowa zachorowań dotyczy dzieci do 14 . roku życia $(4,5)$. Wirus grypy zakaża i następnie uszkadza komórki nabłonka nosa, krtani, tchawicy i oskrzeli (6). Powikłania związane są z ciężkimi 
clinical forms of influenza virus infections $(5,7)$. Influenza is a highly contagious respiratory infection characterized by its sudden onset. The typical symptoms of influenza according to the World Health Organization (WHO) include: fever of $38^{\circ} \mathrm{C}$ or more, chills, muscle aches, headaches, cough, runny nose. The cough may be severe and may last for more than two weeks. Most people recover from these symptoms within seven days. Influenza can be severe, requiring hospitalization, and even fatal, especially in the group of high-risk patients (3). The greatest risk of severe forms of this disease occurs in children up to 5 years of age, people over 65 , pregnant women, chronically ill patients, and people with reduced immunity (5). According to WHO data, 5 to $25 \%$ of the population (5-10\% of adults and $20-30 \%$ of children) are infected with influenza and influenza-like viruses worldwide. Severe course of influenza affects approximately 3-5 million cases each year, and between half a million and one million people die $(3,5,8)$. The estimated annual costs associated with influenza cases and complications amount to approximately EUR 6-14 billion (9).

Converting the numerical data in the population, it can be estimated that in the practice of a family doctor who cares for about 2,000 patients, several hundred patients may become ill each year (6). Influenza vaccination is effective in preventing this disease.

The diagnosis of the pathogenic factor is important for the choice of the treatment method. Rapid antigen tests are an available and fast method which allows visual detection of influenza $A$ and $B$ viruses in less than 30 minutes. However, due to the sensitivity of the tests ranging from 50 to $90 \%$ and their specificity of $90-99 \%$, they should be treated as screening tests. Positive test results are reliable, and false-positive results are relatively rare. Nevertheless, a negative test result does not allow $100 \%$ to exclude the disease, especially if the epidemiological history and the clinical picture indicate influenza (10-13). Doubtful cases can be verified by molecular tests with greater sensitivity and specificity. However, they are not widely available in primary care. It is believed that molecular tests, especially RT-PCR (reverse-transcription polymerase chain reaction), should be performed in the group of patients with a severe course of influenza and/ or the risk of complications or other indications for hospitalization (5).

\section{MATERIAL AND METHODS}

The study included adult patients with symptoms of respiratory tract infection who saw their GP between December 2018 and April 2020. The study was conducted among patients of the Family Health postaciami klinicznymi zakażeń wirusem grypy $(5,7)$. Grypa jest wysoce zakaźną infekcją dróg oddechowych charakteryzująca się nagłym początkiem. Do typowych objawów grypy wg Światowej Organizacji Zdrowia (WHO - World Health Organization) należą: gorączka $38{ }^{\circ} \mathrm{C}$ lub więcej, dreszcze, bóle mięśni, bóle głowy, kaszel, katar. Kaszel może być bardzo nasilony i trwać ponad 2 tygodnie. U większości osób objawy ustępują w ciągu 7 dni. Grypa może mieć przebieg ciężki, wymagający hospitalizacji, a nawet śmiertelny, zwłaszcza w grupie pacjentów wysokiego ryzyka (3). Największe ryzyko ciężkich postaci tej choroby występuje u dzieci w wieku do 5 lat, osób po 65. roku życia, kobiet w ciąży, pacjentów przewlekle chorych, osób ze zmniejszoną odpornością (5). Zgodnie z danymi WHO, na świecie z powodu zakażenia grypą i wirusami grypopodobnymi, choruje corocznie od 5 do $25 \%$ populacji (5-10\% dorosłych i $20-30 \%$ dzieci). Ciężki przebieg grypy dotyczy rocznie ok. 3-5 milionów zachorowań, a umiera od pół miliona do 1 miliona ludzi $(3,5,8)$. Szacowane roczne koszty związane z zachorowaniami i powikłaniami grypy wynoszą ok. 6-14 mld euro (9). Przeliczając dane liczbowe w populacji można szacować, że w praktyce lekarza rodzinnego mającego pod opieką ok. 2000 pacjentów może zachorować kilkuset pacjentów rocznie (6). Szczepienia przeciw grypie są skuteczne w zapobieganiu tej chorobie.

Rozpoznanie czynnika patogennego infekcji dróg oddechowych ma swoje uzasadnienie dla wyboru metody leczenia. Dostępną i szybką metodą są szybkie testy antygenowe, które pozwalają na wizualną detekcję wirusów grypy A i B w czasie nieprzekraczającym 30 minut. Jednak ze względu na czułość testów wahającą się od 50 do 90\% i specyficzność 90-99\% należy traktować je jako badania przesiewowe. Dodatnie wyniki testów są wiarygodne, a fałszywie dodatnie wyniki zdarzają się stosunkowo rzadko. Mimo to, ujemny wynik testu nie pozwala w $100 \%$ na wykluczenie choroby, szczególnie jeśli wywiad epidemiologiczny i obraz kliniczny wskazują na grypę (10-13). Przypadki wątpliwe mogą zostać zweryfikowane za pomocą badań molekularnych o większej czułości i specyficzności. Nie są one jednak szeroko dostępne w podstawowej opiece zdrowotnej. Uważa się, że testy molekularne, a szczególnie RT-PCR (reverse-transcription polymerase chain reaction, reakcja łańcuchowa polimerazy z odwrotna transkrypcja) powinny być wykonane w grupie pacjentów z ciężkim przebiegiem grypy i/lub ryzykiem powikłań lub innymi wskazaniami do hospitalizacji (5).

\section{MATERIAŁ I METODY}

Do badania kwalifikowano dorosłych pacjentów z objawami infekcji dróg oddechowych, którzy zgłosili się do lekarza rodzinnego w okresie od grudnia 
Care Centre in Gostyń, Greater Poland Province. Participation in the study was voluntary, confirmed by the patients' written consent. The study was approved by the Bioethics Committee on January 10, 2019 at Karol Marcinkowski Medical University in Poznań Resolution No 84/19.

Among the group of patients with symptoms of respiratory tract infection, patients with symptoms of influenza-like illness were selected according to the following criteria: sudden onset fever and $\geq 1$ clinical symptom of respiratory system such as cough, sore throat, rhinitis or nasal congestion and $\geq 1$ systemic symptom such as headache and muscles, sweating or chills, fatigue - persisting $<72 \mathrm{~h}$. In patients with symptoms of influenza-like illness, rapid flu tests Actim Influenza A\&B test (Medix Biochemica) were performed.

Influenza has been diagnosed in patients with typical flu symptoms and a positive antigen test result.

One patient was diagnosed with influenza on the basis of its characteristic clinical picture, despite a negative antigen test result, based on the fact that this patient had contact with a family member who had been confirmed with influenza by an antigen test.

The remaining patients with clinical symptoms that did not suggest influenza or presented doubtful symptoms and patients with negative antigen test results were included in the group of patients with symptoms of respiratory tract infection of probably different etiology.

In the analysis, the clinical symptoms, age, the abnormalities in the physical examination, comorbidities, nicotinism, vaccination status, final diagnosis made, probable etiology, the result of the Actim Influenza A\&B rapid antigen test (Medix Biochemica) for influenza virus infection, ordered $\mathrm{x}$-rays, laboratory tests were taken into account.

The abnormalities in the physical examination were defined as follows (14):

- tachycardia - an increase in heart rate above 100 beats;

- enlarged lymph nodes - enlarged lymph nodes (more than $1 \mathrm{~cm}$ ) - localized lymphadenopathy, in this case cervical, submandibular +/- parotid, sometimes with local pain, mobile nodes in relation to the ground, single;

- reddening of the throat - swelling and redness of the pharyngeal mucosa without involvement of the throat lymphoid ring;

- purulent discharge on the back of the throat mucopurulent discharge with a greyish, green or yellow colour flowing down the back of the throat;

- acute tonsillitis - vivid red or blood-red mucosa, swelling, clearly delimited clumps of exudate on the tonsils, along with other symptoms suggesting
2018 do kwietnia 2020 roku. Badanie przeprowadzono wśród pacjentów Przychodni Lekarza Rodzinnego w Gostyniu, woj. wielkopolskie. Udział w badaniu był dobrowolny, potwierdzony pisemną zgodą pacjentów. Na przeprowadzenie badania uzyskano zgodę Komisji Bioetycznej przy Uniwersytecie Medycznym im. K. Marcinkowskiego w Poznaniu z dnia 10 stycznia 2019 roku - uchwała nr 84/19.

Z grupy pacjentów z objawami infekcji dróg oddechowych wyłoniono pacjentów z objawami choroby grypopodobnej wg następujących kryteriów: gorączka o nagłym początku oraz $\geq 1$ objaw kliniczny ze strony układu oddechowego, taki jak kaszel, ból gardła, nieżyt nosa lub uczucie zatkania nosa oraz $\geq 1$ objaw ogólnoustrojowy, taki jak ból głowy i mięśni, poty lub dreszcze, zmęczenie utrzymujących się $<72 \mathrm{~h}$.

$\mathrm{U}$ pacjentów $\mathrm{z}$ objawami choroby grypopodobnej wykonywano szybki test w kierunku grypy Actim Influenza A\&B (Medix Biochemica). U pacjentów z typowymi objawami grypy oraz dodatnim wynikiem testu antygenowego rozpoznano grypę.

W przypadku jednego pacjenta postawiono rozpoznanie grypy na podstawie charakterystycznego obrazu klinicznego pomimo ujemnego wyniku testu antygenowego, w związku z kontaktem tego pacjenta z członkiem rodziny, u którego potwierdzono grypę testem antygenowym.

Pozostałych pacjentów z objawami klinicznymi, które nie sugerowały grypy lub prezentowały objawy wątpliwe oraz z ujemnym wynikiem testu antygenowego zakwalifikowano do grupy pacjentów z objawami zakażenia dróg oddechowych o prawdopodobnie innej etiologii.

W analizie uwzględniono występujące objawy kliniczne, odchylenia $\mathrm{w}$ badaniu przedmiotowym, wiek, choroby współistniejące, nikotynizm, status szczepień, postawione rozpoznanie końcowe, prawdopodobną etiologię, wynik szybkiego testu antygenowego w kierunku zakażenia wirusem grypy, zlecone badania radiologiczne, badania laboratoryjne.

Odchylenia w badaniu przedmiotowym definiowano następująco (14):

- tachykardia - przyspieszenie akcji serca powyżej 100 uderzeń

- powiększone węzły chłonne - powiększenie węzłów chłonnych (powyżej $1 \mathrm{~cm}$ ) o charakterze limfadenopatii zlokalizowanej, w tym przypadku szyjnej, podżuchwowej +/- przyusznej, niekiedy z towarzyszącą miejscową bolesnością, węzły ruchome względem podłoża, pojedyncze;

- zaczerwienienie gardla - obrzęk i zaczerwienienie błony śluzowej gardła, bez zajęcia pierścienia tkanki chłonnej gardła

- ropna wydzielina na tylnej ścianie gardla - śluzowo-ropna wydzielina o szarawym, zielonym lub 
streptococcal inflammation: tender, enlarged anterior cervical lymph nodes $>$ or $=2 \mathrm{~cm}$ and fever above 38 degrees Celsius; no tests were performed to confirm the presence of the A group B-haemolytic streptococci in throat swabs;

- nasal discharge - nasal discharge found during anterior rhinoscopy - most often watery, sometimes mucous or whitish-yellow;

- turbinate hypertrophy - enlargement of the inferior $+/-$ middle nasal turbinates found in anterior rhinoscopy using the Hartman speculum;

- nasal congestion - redness and increased nasal mucosa secretion found in anterior rhinoscopy;

- purulent discharge in the nasal cavity - purulent content of green or brown-green colour in the nasal cavities found in anterior rhinoscopy;

- shallow, irregular breathing - shortness of breath as a result of exhausting the strength of the respiratory muscles;

- symptoms of hypoxia - diagnosed when, apart from infectious symptoms, there were symptoms of hypoxia such as: tachycardia, tachypnoea, blue lips, lividity of the nail plates, confusion, dizziness or headaches, anxiety;

- increased work of accessory respiratory muscles - increased work of the sternocleidomastoid, trapezius and inclined muscles, visible tightening of the intercostal spaces;

- tachypnoea - accelerated breathing > 30/min;

- stridor - inspiratory laryngeal breath sound;

- reduced vesicular breath sound - reduced vesicular breath sound found during auscultation of the chest;

- pathological bronchial breath sound - bronchial breath sound heard over the peripheral areas of the respiratory tract;

- wheezing - continuous sonorous breath sounds (persisting $>0.25 \mathrm{~s}$ ) of high frequency;

- pleural friction - changes as a result of rubbing pleural plaques as a result of fibrin deposition in the course of the inflammatory process;

- dry rales - continuous low-frequency sonorous breath sounds;

- crackles - fine rales, i.e. dull, short, intermittent breathing sounds.

Comorbidities were defined as follows:

- atherosclerosis - patients with confirmed atherosclerotic lesions in the carotid, cerebral arteries or arteries in lower extremities; patients with ischemic heart disease or post-stroke patients were classified separately;

- muscle diseases -18 patients - these were patients with primary muscular diseases as well as overload changes secondary to locomotor system diseases: one patient with myasthenia gravis, one patient żółtym zabarwieniu spływająca po tylnej ścianie gardła

- ostre zapalenie migdałków podniebiennych - żywoczerwona lub krwistoczerwona błona śluzowa, obrzęk, wyraźnie odgraniczone skupiska wysięku na migdałkach, wraz z innymi objawami sugerującymi zapalenie paciorkowcowe: tkliwe, powiększone węzły chłonne szyjne przednie $>l u b=2 \mathrm{~cm}$ oraz gorączka powyżej 38 stopni Celsjusza; nie wykonywano badań potwierdzających obecność paciorkowców ß-hemolizujących grupy A w wymazie $\mathrm{z}$ gardła;

- wydzielina w przewodach nosowych - stwierdzana podczas wykonywania rynoskopii przedniej obecność wydzieliny nosowej - najczęściej o charakterze wodnistym, czasami śluzowym lub białawo-żółtym

- przerost małżowin nosowych - powiększenie małżowin nosowych dolnych +/- środkowych stwierdzane w rynoskopii przedniej za pomoca wziernika Hartmana

- przekrwienie błon śluzowych nosa - zaczerwienie i zwiększona sekrecja błony śluzowej nosa stwierdzana w rynoskopii przedniej

- ropna wydzielina w jamie nosowej - treść o charakterze ropnym, koloru zielonego lub brunatno -zielonego $\mathrm{w}$ jamach nosowych stwierdzana $\mathrm{w}$ rynoskopii przedniej

- płytkie, nieregularne oddechy - spłycenie oddechu w wyniku wyczerpania siły mięśni oddechowych

- objawy niedotlenienia - rozpoznawano gdy poza objawami infekcyjnymi występowały objawy hipoksji takie jak: tachykardia, tachypnoe, zasinienie ust, zasinienie płytek paznokciowych, splątanie, zawroty lub bóle głowy, niepokój

- wzmożona praca dodatkowych mięśni oddechowych - wzmożona praca mięśni mostkowo-obojczykowo-sutkowych, czworobocznych, pochyłych, widoczne zaciąganie przestrzeni międzyżebrowych

- tachypnoe - oddech przyśpieszony $>30 / \mathrm{min}$

- stridor - wdechowy świst krtaniowy

- ściszony szmer pęcherzykowy - ściszenie szmeru pęcherzykowego stwierdzone podczas osłuchiwania klatki piersiowej

- szmer oskrzelowy patologiczny - szmer oskrzelowy słyszalny nad obwodowymi obszarami dróg oddechowych

- świsty - dźwięczne szmery o charakterze ciągłym (trwające $>0,25 \mathrm{~s}$ ) o wysokiej częstotliwości

- tarcie opłucnej - zmiany w wyniku ocierania blaszek opłucnej, w wyniku odkładania się włóknika $\mathrm{w}$ przebiegu procesu zapalnego

- furczenia - dźwięczne szmery o charakterze ciągłym o niskiej częstotliwości 
with rheumatic polymyalgia, one patient with posttraumatic muscle atrophy, the rest with overload problems caused by degenerative changes of the spine joints and peripheral joints;

- vascular aneurysm - diagnosed in six out of 631 patients; three patients with abdominal aortic aneurysm (one after vascular surgery, two patients under the observation of a vascular surgeon), one with clinically asymptomatic thoracic aortic aneurysm (conservative treatment, observation, under cardiological supervision), two patients with cerebral arterial aneurysm (one a person pre-qualified for surgery, the other person under observation).

Other definitions:

- breathing disorders - understood as a subjective clinical symptom reported by patients, e.g. shortness of breath, feeling of heaviness in breathing, problem with taking a deep breath;

- fever-body temperature above 38 degrees Celsius;

- low-grade fever - between 37.5 and 38 degrees Celsius;

- bacterial superinfection - considered in cases of prolonged fever and other acute symptoms $>3$ days, symptoms of lower respiratory tract infection, dyspnoea, severe pain in the sinuses, head and ear; retrosternal chest pain;

- past smokers - non-smokers for 5 years and more;

- non-smokers - patients who never smoked;

- smokers - current smokers.

The diagnoses were made according to the international disease classification ICD-10.

The diagnosis of influenza virus infection was made on the basis of a clinical examination with the appearance of typical influenza symptoms such as sudden onset, fever, chills, cough, fatigue and headache, muscle aches, sore throat, and with a positive result of the Actim Influenza A\&B rapid antigen test (Medix Biochemica). The eligibility criteria for the test were: sudden onset fever and $\geq 1$ clinical symptom of respiratory system such as cough, sore throat, rhinitis or feeling of stuffy nose and $\geq 1$ systemic symptom such as headache, muscle pain, sweating or chills, fatigue - persisting $<72 \mathrm{~h}$.

Statistical analysis was performed with the use of the STATISTICA program. Quantitative variables were analyzed using t- and Mann-Whitney's tests depending on the analyzed normal distribution in the Shapiro-Wilk test. Qualitative variables were compared with the chi-squared test. $\mathrm{P}$ values $<0.05$ were considered statistically significant. Taking into account the parameters demonstrating statistical significance, a regression analysis was performed. The OR (odds ratios), the CIs (confidens intervals) of which did not contain 1 , were considered significant.
- trzeszczenia - rzężenia drobnobańkowe czyli niedźwięczne, krótkie, przerywane szmery oddechowe

Choroby współistniejące definiowano w następujący sposób:

- miażdżyca - pacjenci $\mathrm{z}$ potwierdzonymi w badaniach obrazowych zmianami miażdżycowymi w tętnicach szyjnych, mózgowych lub tętnicach kk. dolnych; pacjenci $\mathrm{z}$ chorobą niedokrwienną serca lub po udarze mózgu byli zakwalifikowani osobno; choroby mięśni - 18 pacjentów - byli to pacjenci z pierwotnymi chorobami mięśni, jak i wtórnymi do chorób układu ruchu zmianami przeciążeniowymi: 1 pacjentka $\mathrm{z}$ miastenią, 1 pacjentka $\mathrm{z}$ polimialgią reumatyczną, 1 pacjent $\mathrm{z}$ zanikiem mięśni pourazowym, pozostali z problemami przeciążeniowymi spowodowanymi zmianami zwyrodnieniowymi stawów kręgosłupa i stawów obwodowych;

- tętniak naczyń - rozpoznanie dotyczyło 6 osób spośród 631 pacjentów; 3 pacjentów z tętniakiem aorty brzusznej (1 po operacji naczyniowej, 2 osoby w obserwacji chirurga naczyniowego), $1 \mathrm{z}$ bezobjawowym klinicznie tętniakiem aorty piersiowej (leczony zachowawczo, obserwacja, pod nadzorem kardiologicznym), 2 osoby z tętniakiem tętnic mózgowych (jedna osoba zakwalifikowana wstępnie do zabiegu, druga osoba w obserwacji);

Inne definicje:

- zaburzenia oddychania - rozumiano jako subiektywny objaw kliniczny zgłaszany przez pacjenta np. duszność, uczucie ciężkości oddechu, problem z nabraniem głębokiego oddechu;

- gorączka - temperatura ciała powyżej 38 stopni Celsjusza

- $\quad$ stan podgorączkowy - między 37,5 a 38 stopnia Celsjusza

- nadkażenie bakteryjne - rozważano w przypadkach przedłużającej się gorączki i innych ostrych objawów > 3 dni, objawów infekcji dolnych dróg oddechowych, pojawienia się duszności, pojawienia się silnego bólu zatok, głowy, ucha; bólu zamostkowego w klatce piersiowej;

- osoby palące w przeszlości - niepalące od 5 lat i więcej

- osoby niepalące - nigdy nie paliły

- osoby palące - palące obecnie

Rozpoznania stawiano zgodnie $\mathrm{z}$ międzynarodową klasyfikacją chorób ICD-10.

Rozpoznanie zakażenia wirusem grypy stawiano na podstawie badania klinicznego przy wystąpieniu typowych objawów grypy, takich jak: nagły początek choroby, gorączka, dreszcze, kaszel, zmęczenie i ból głowy, bóle mięśniowe, ból gardła oraz z dodatnim wynikiem szybkiego testu antygenowego Actim Influenza A\&B (Medix Biochemica). Kryterium kwalifikacji do wy- 
Parameters with statistical significance in the one-way analysis were analyzed in multivariate analysis.

\section{RESULTS}

631 people with symptoms of respiratory tract infection were examined, who reported to the GP surgery in the period from December 2018 to April 2020. In the study group, 356 rapid antigen tests for influenza were performed, i.e. in $56 \%$ of all patients. Influenza was diagnosed in 91 patients (91p.), 50 women and 41 men. The mean age of the patients was 47.3 years, the age range was $22-89$ years. In 90 people, infection with the influenza virus was confirmed with the Actim Influenza A\&B test (Medix Biochemica), in one patient the diagnosis was made on the basis of the clinical picture and contact with a family member with confirmed flu, without confirmation with a rapid test.

In the group of patients diagnosed with influenza, the following clinical symptoms occurred more frequently than in the group of patients with respiratory tract infections in whom the result of the antigen test was negative and the clinical picture did not indicate influenza: fever $(93 \%, 85 \mathrm{p}$.$) , cough (88 \%, 80 \mathrm{p}$.), muscle aches $(98 \%, 89 \mathrm{p}$.$) , headache (67 \%, 61 \mathrm{p}$.$) , sore$ throat $(53 \%, 49 \mathrm{p}$.$) , chest pain (55 \%, 50 \mathrm{p}$.$) , breathing$ difficulties $(37 \%, 34 \mathrm{p}$.). Symptoms which were less frequent in relation to the group of patients with respiratory tract infections which were not classified as influenza were: nasal obstruction, earache, nasal discharge and low-grade fever. The mean duration of fever in patients up to the GP visit and the total duration of fever were longer in patients with diagnosed influenza than in the group with respiratory infections of potentially different etiology.

In physical examination, patients diagnosed with influenza showed significantly more frequently: tachycardia $(59 \%, 54 \mathrm{p}$.$) , tachypnoea (26 \%, 24 \mathrm{p}$.), reduction in vesicular breath sound $(25 \%, 23 \mathrm{p}$.), shallow or irregular breathing $(13 \%, 12 \mathrm{p}$.), increased work of accessory respiratory muscles $(13 \%, 12 \mathrm{p}$.), pathological bronchial breath sound $(10 \%, 9 \mathrm{p}$.), symptoms of hypoxia $(5 \%, 5 \mathrm{p}$.). The following was reported less frequently than in patients with a respiratory tract infection of other etiology: enlarged cervical lymph nodes $(9 \%, 8 \mathrm{p}$.), purulent changes in the throat $(5 \%, 5 p$.$) , turbinate hypertrophy (24 \%, 22 p$.) and nasal congestion $(38 \%, 35 \mathrm{p}$.$) . The observed symptoms$ and abnormalities in the physical examination are summarized in Table I.

In the studied group of patients with influenza, one person (1\%) was vaccinated against influenza, while in the remaining patients vaccination was not performed. In the group of patients with respiratory tract infection konania testu były: gorączka o nagłym początku oraz $\geq 1$ objaw kliniczny ze strony układu oddechowego, taki jak kaszel, ból gardła, nieżyt nosa lub uczycie zatkania nosa oraz $\geq 1$ objaw ogólnoustrojowy, taki jak ból głowy i mięśni, poty lub dreszcze, zmęczenie - utrzymujące się $<72 \mathrm{~h}$.

Analizy statystycznej dokonano przy użyciu programu STATISTICA. Zmienne ilościowe analizowano przy użyciu testów t-Studenta i Manna-Whitneya w zależności od przeanalizowanego rozkładu normalnego w teście Shapiro-Wilka. Zmienne jakościowe porównywano testem chi-kwadrat. Za istotne statystycznie uznano wartości $\mathrm{p}<0,05$. Uwzględniając parametry wykazujące istotność statystyczną wykonano analizę regresji. Za istotne uznano ilorazy szans (OR- odds ratio), których przedziały ufności (CI -ang. confidence interval) nie zawierały 1 . Parametry z istotnością statystyczną $\mathrm{w}$ analizie jednoczynnikowej przeanalizowano w analizie wieloczynnikowej.

\section{WYNIKI}

Przebadano 631 osób z objawami infekcji dróg oddechowych, które zgłosiły się do gabinetu lekarza rodzinnego w okresie od grudnia 2018 do kwietnia 2020 roku. W badanej grupie wykonano 356 szybkich testów antygenowych w kierunku grypy, tj. u 56\% ogółu pacjentów. Grypę rozpoznano u 91 pacjentów (91p.); 50 kobiet i 41 mężczyzn. Średnia wieku pacjentów wynosiła 47,3 lat, zakres wieku 22-89 lat. U 90 osób potwierdzono zakażenie wirusem grypy testem Actim Influenza A\&B (Medix Biochemica), u 1 osoby rozpoznanie postawiono na podstawie obrazu klinicznego oraz kontaktu z osobą z rodziny z potwierdzoną grypą, bez potwierdzenia szybkim testem.

W grupie pacjentów z rozpoznaną grypą następujące objawy kliniczne występowały częściej niż w grupie pacjentów z zakażeniami dróg oddechowych, u których test antygenowy był ujemny, a obraz kliniczny nie wskazywał na grypę: gorączka $(93 \%, 85$ p.), kaszel (88\%, 80 p.), bóle mięśni (98\%, 89 p.), bóle głowy (67\%, 61 p.), ból gardła (53\%, 49 p.), bóle w klatce piersiowej $(55 \%, 50$ p.), zaburzenia oddychania $(37 \%, 34$ p.). Do rzadziej występujących objawów w stosunku do grupy pacjentów z zakażeniami dróg oddechowych niezakwalifikowanymi jako grypa należały: niedrożność nosa, ból ucha, wydzielina z nosa oraz stan podgorączkowy. Średni czas trwania gorączki u pacjentów do czasu wizyty w POZ oraz całkowity czas trwania gorączki był dłuższy u pacjentów z rozpoznaną grypą w stosunku do grupy z infekcjami dróg oddechowych o potencjalnie innej etiologii.

W badaniu fizykalnym u pacjentów z rozpoznaną grypą stwierdzano istotnie częściej: tachykardię (59\%, 54 p.), tachypnoe $(26 \%, 24$ p.), ściszenie szmeru pę- 
of other etiology, 36 were vaccinated (statistically significant difference).

Cigarette smokers accounted for $21 \%$ (19p.), past smokers $13 \%$ (12p.).

Among comorbidities in the studied group of patients with influenza the following were observed: spine diseases $(42 \%, 38 \mathrm{p}$.), arterial hypertension $(32 \%$, 29 p.), obesity $(34 \%, 31$ p.), hypercholesterolaemia $(29 \%, 26 p$.$) , gastritis (24 \%, 22 \mathrm{p}$.$) , peripheral joint$ diseases $(16 \%, 15 \mathrm{p}$.$) , muscle diseases (20 \%, 18 \mathrm{p}$.$) ,$ diabetes or impaired glucose tolerance (IGT) $(20 \%$, 18p.). The following were diagnosed significantly more often compared to patients with respiratory tract infections of other etiology: inflammatory diseases of the stomach, muscle diseases $(20 \%, 18 \mathrm{p}$.), migraine headaches $(12 \%, 11 \mathrm{p}$.$) , atherosclerosis (13 \%, 12 \mathrm{p}$.$) ,$ liver diseases $(9 \%, 8 p$.$) , tooth decay (14 \%, 13 p$.$) , skin$ diseases $(13 \%, 12 \mathrm{p}$.).

Probable bacterial superinfection was diagnosed in 20 patients from the study group. In 19 patients (20\%) antibiotic therapy was finally administered. Bronchitis or pneumonia requiring antibiotic therapy was diagnosed in $14(15 \%)$ patients. Chest X-ray was taken in 17 patients, on the basis of which pneumonia was diagnosed in seven cases. Due to chest pains, an ECG was performed in 29 patients. One patient was diagnosed with a complication in the form of myocarditis, requiring and confirmed during hospitalization. In five patients (5\%) complications in the form of secondary bacterial superinfection of the upper respiratory tract were diagnosed - acute sinusitis $(2 \%, 2 \mathrm{p}$.$) , acute otitis media (3 \%, 3 \mathrm{p}$.). In total, symptoms of otitis media were diagnosed in 9 patients $(10 \%)$ - antibiotic therapy was administered in three cases suspected of secondary bacterial infection.

Non-steroidal anti-inflammatory drugs (NSAIDs) were administered in $96 \%$ of patients (88p.), oseltamivir was used in $76 \%$ (70p.), glucocorticosteroids in $7 \%$ (6p.), other drugs in $41 \%$ (38p.).

Treatment of influenza virus infection with oseltamivir was administered in patients with risk factors for severe course of influenza, in cases where it was possible to start treatment up to 48 hours after the onset of symptoms $(15,16)$, in adult patients with severe, complicated or progressive course of influenza - in total in 70 cases.

GCS (glucocorticosteroids) were administered in six patients - two patients with exacerbation of chronic bronchitis, one patient with bronchial asthma, one patient with COPD (chronic obstructive pulmonary disease), two patients with pneumonia. GCS were used in the form of nebulization in three patients, in the form of a powder aerosol in one patient, in the oral form in two patients. cherzykowego $(25 \%, 23$ p.), płytkie lub nieregularne oddechy $(13 \%, 12 \mathrm{p}$.), wzmożoną pracę dodatkowych mięśni oddechowych (13\%, 12 p.), szmer oskrzelowy patologiczny $(10 \%, 9$ p.), objawy niedotlenienia $(5 \%, 5$ p). Rzadziej niż u pacjentów z infekcją dróg oddechowych o innej etiologii stwierdzano: powiększone węzły chłonne szyjne $(9 \%, 8$ p.), zmiany ropne w gardle $(5 \%, 5$ p.), przerost małżowin nosowych $(24 \%, 22$ p.) oraz przekrwienie błony śluzowej nosa $(38 \%, 35$ p.). Obserwowane objawy i odchylenia w badaniu przedmiotowym zestawiono w Tabeli I (Tab. I).

W badanej grupie pacjentów z grypą 1 osoba (1\%) była zaszczepiona przeciw tej chorobie, u pozostałych szczepienia nie wykonano. W grupie pacjentów z zakażeniem dróg oddechowych o innej etiologii zaszczepionych było 36 osób (różnica istotna statystycznie).

Osoby palące papierosy wśród osób z grypą stanowiły $21 \%$ (19 p.), osoby palące w przeszłości $13 \%$ (12 p.).

Wśród chorób towarzyszących w badanej grupie pacjentów z grypą obserwowano: choroby kręgosłupa $(42 \%, 38$ p.), nadciśnienie tętnicze $(32 \%$, 29 p.), otyłość (34\%, 31 p.), hipercholesterolemię $(29 \%, 26$ p.), choroby zapalne żołądka $(24 \%, 22$ p.), choroby stawów obwodowych $(16 \%, 15$ p.), choroby mięśni (20\%, 18 p.), cukrzycę lub upośledzenie tolerancji glukozy (IGT) $(20 \%, 18$ p.). Istotnie częściej w stosunku do pacjentów z zakażeniami dróg oddechowych o innej etiologii stwierdzano: choroby zapalne żołądka, choroby mięśni $(20 \%, 18$ p.), migrenowe bóle głowy( $(12 \%, 11$ p.), miażdżycę (13\%, 12 p.), choroby wątroby $(9 \%, 8$ p.), próchnicę zębów $(14 \%, 13$ p.), choroby skóry $(13 \%, 12$ p.).

U 20 pacjentów z badanej grupy rozpoznano prawdopodobne nadkażenie bakteryjne. U 19 pacjentów (20\%) ostatecznie została zastosowana antybiotykoterapia. U 14 (15\%) pacjentów rozpoznano zapalenie oskrzeli lub zapalenie płuc wymagające zastosowania antybiotykoterapii. U 17 pacjentów wykonano zdjęcie RTG klatki piersiowej, na podstawie którego w 7 przypadkach rozpoznano zapalenie płuc. $Z$ uwagi na bóle w klatce piersiowej u 29 osób wykonano EKG. U jednego pacjenta rozpoznano powikłanie w postaci zapalenia mięśnia sercowego, wymagające i potwierdzone w czasie hospitalizacji. U 5 pacjentów (5\%) rozpoznano powikłania w postaci wtórnego nadkażenia bakteryjnego górnych dróg oddechowych - ostre zapalenie zatok $(2 \%, 2$ p.), ostre zapalenie ucha środkowego $(3 \%, 3 \mathrm{p}$.). Ogółem objawy zapalenia ucha środkowego rozpoznano u 9 pacjentów (10\%) - antybiotykoterapię zastosowano w 3 przypadkach podejrzanych o wtórną infekcję bakteryjną.

Niesteroidowe leki przeciwzapalne (NLPZ) zastosowano u 96\% pacjentów (88p.), inne leki u 41\% (38p.). 
Tabe I. Comparison of patients with influenza and other respiratory infections

Tabela I. Porównanie pacjentów z grypą i innymi infekcjami dróg oddechowych

\begin{tabular}{|c|c|c|c|c|c|}
\hline & $\begin{array}{l}\text { All } \\
\text { Patients } \\
\text { n (\%) }\end{array}$ & $\begin{array}{c}\text { Flu patients } \\
\text { n }(\%)\end{array}$ & $\begin{array}{c}\text { Patients with } \\
\text { respiratory } \\
\text { infections of } \\
\text { other etiology, } \\
\text { n (\%) }\end{array}$ & $p$ & OR (CI) \\
\hline Group size & 631 & $91(14 \%)$ & $540(86 \%)$ & - & - \\
\hline Median age, years (IQR) & $45(33-60)$ & $46(34-59)$ & $45(34-61)$ & 0.842 & \\
\hline Women & 366 & $50(55 \%)$ & $316(59 \%)$ & \multirow{2}{*}{0.5229} & - \\
\hline Men & 265 & $41(45 \%)$ & $224(41 \%)$ & & - \\
\hline X-ray diagnostics & $120(19 \%)$ & $17(18 \%)$ & $103(19 \%)$ & 0.9296 & - \\
\hline Influenza vaccination & $37(6 \%)$ & $1(1 \%)$ & $36(7 \%)$ & $0.0365^{*}$ & \\
\hline Pregnancy & $3(0.5 \%)$ & $0(0 \%)$ & $3(0.6 \%)$ & 0.4756 & - \\
\hline Smoking cigarettes currently & $131(21 \%)$ & $19(21 \%)$ & $112(21 \%)$ & 0.9760 & - \\
\hline Past cigarette smoking & $77(12 \%)$ & $12(13 \%)$ & $65(12 \%)$ & 0.7566 & - \\
\hline \multicolumn{4}{|c|}{ Treatment administered } & $p$ & OR (CI) \\
\hline Antibiotic administered & $269(42 \%)$ & $19(21 \%)$ & $250(46 \%)$ & $0.00001^{*}$ & $\begin{array}{c}0.31 \\
(0.18-0.52) \\
\end{array}$ \\
\hline Oseltamivir administered & $70(11 \%)$ & $70(76 \%)$ & $0(0 \%)$ & $0.00001^{*}$ & - \\
\hline GCS administered & $83(13 \%)$ & $6(7 \%)$ & $77(14 \%)$ & $0.0453^{*}$ & $\begin{array}{c}0.42 \\
(0.18-1.01) \\
\end{array}$ \\
\hline NSAID administered & $448(71 \%)$ & $88(97 \%)$ & $60(67 \%)$ & $0.00001^{*}$ & $\begin{array}{c}14.67 \\
(4.58-47.0) \\
\end{array}$ \\
\hline \multicolumn{4}{|c|}{ Symptoms } & $p$ & OR (CI) \\
\hline Hoarseness & $112(18 \%)$ & $14(15 \%)$ & $98(18 \%)$ & 0.5233 & - \\
\hline Fever & $298(47 \%)$ & $85(93 \%)$ & $213(39 \%)$ & $0.00001^{*}$ & $\begin{array}{c}21.75 \\
(9.34-50.67) \\
\end{array}$ \\
\hline Cough & $350(55 \%)$ & $79(86 \%)$ & $271(50 \%)$ & $0.00001^{*}$ & $\begin{array}{c}6.54 \\
(3.48-12.27) \\
\end{array}$ \\
\hline $\begin{array}{c}\text { Total Fever Days (Days) - } \\
\text { median (IQR) }\end{array}$ & $0(0-1)$ & $3(2-4)$ & $0(0-2)$ & $0.00001^{*}$ & $\begin{array}{c}2.67 \\
(2.21-3.24) \\
\end{array}$ \\
\hline $\begin{array}{c}\mathrm{N} \text { of fever days before visiting } \\
\text { primary health care (days) - } \\
\text { median (IQR) }\end{array}$ & $0(0-2)$ & $2(1-2)$ & $0(0-1)$ & $0.00001^{*}$ & $\begin{array}{c}3.62 \\
(2.74-4.77)\end{array}$ \\
\hline Increased body temperature & $229(36 \%)$ & $6(7 \%)$ & $223(41 \%)$ & $0.00001^{*}$ & $\begin{array}{c}0.10 \\
(0.04-0.23)\end{array}$ \\
\hline Ear pain & $112(18 \%)$ & $9(10 \%)$ & $103(19 \%)$ & $0.0339 *$ & $\begin{array}{c}0.47 \\
(0.23-0.96) \\
\end{array}$ \\
\hline Headaches & $244(39 \%)$ & $60(66 \%)$ & $184(34 \%)$ & $0.00001^{*}$ & $\begin{array}{c}3.75 \\
(2.34-5.99) \\
\end{array}$ \\
\hline Muscle aches & $135(21 \%)$ & $89(98 \%)$ & $46(8 \%)$ & $0.00001^{*}$ & $\begin{array}{c}477.89 \\
(113.95-2004.20)\end{array}$ \\
\hline Chest pains & $121(20 \%)$ & $50(55 \%)$ & $71(13 \%)$ & $0.00001^{*}$ & $\begin{array}{c}165.14 \\
(39.31-693.70) \\
\end{array}$ \\
\hline Breathing disorders & $93(15 \%)$ & $34(37 \%)$ & $59(11 \%)$ & $0.00001^{*}$ & $\begin{array}{c}4.86 \\
(2.94-8.05) \\
\end{array}$ \\
\hline Runny nose & $201(32 \%)$ & $9(10 \%)$ & $192(35 \%)$ & $0.00001^{*}$ & $\begin{array}{c}0.20 \\
(0.10-0.41) \\
\end{array}$ \\
\hline Nasal obstruction & $128(20 \%)$ & $24(26 \%)$ & $104(19 \%)$ & 0.1185 & - \\
\hline
\end{tabular}


Aneta Rzepka, Anna Mania

\begin{tabular}{|c|c|c|c|c|c|}
\hline \multicolumn{4}{|c|}{ Abnormalities in physical examination } & \multirow{2}{*}{$\begin{array}{c}\boldsymbol{p} \\
0.00001^{*}\end{array}$} & \multirow{2}{*}{$\begin{array}{c}\text { OR (CI) } \\
7.2(4.48- \\
11.58)\end{array}$} \\
\hline Tachycardia & $145(23 \%)$ & $54(59 \%)$ & $91(17 \%)$ & & \\
\hline Enlarged cervical lymph nodes & $103(16 \%)$ & $8(9 \%)$ & $95(18 \%)$ & $0.0356^{*}$ & $\begin{array}{c}0.45 \\
(0.21-0.96) \\
\end{array}$ \\
\hline $\begin{array}{l}\text { Purulent discharge on the back } \\
\text { of the throat }\end{array}$ & $107(17 \%)$ & $5(5 \%)$ & $102(19 \%)$ & $0.0016^{*}$ & $\begin{array}{c}0.25 \\
(0.10-0.63) \\
\end{array}$ \\
\hline Tonsillitis & $70(11 \%)$ & $1(1 \%)$ & $69(13 \%)$ & $0.001^{*}$ & $\begin{array}{c}0.08 \\
(0.01-0.55)\end{array}$ \\
\hline Discharge in the nasal cavity & $273(43 \%)$ & $17(19 \%)$ & $256(47 \%)$ & $0.00001^{*}$ & $\begin{array}{c}0.26 \\
(0.15-0.44)\end{array}$ \\
\hline Nasal turbinate hypertrophy & $225(35 \%)$ & $22(24 \%)$ & $203(38 \%)$ & $0.0134^{*}$ & $\begin{array}{c}0.53 \\
(0.32-0.88)\end{array}$ \\
\hline Nasal congestion & $321(50 \%)$ & $35(38 \%)$ & $286(53 \%)$ & $0.0105^{*}$ & $\begin{array}{c}0.56 \\
(0.35-0.88) \\
\end{array}$ \\
\hline Purulent nasal discharge & $53(8 \%)$ & $2(2 \%)$ & $51(9 \%)$ & $0.0211^{*}$ & $\begin{array}{c}0.22 \\
(0.05-0.90)\end{array}$ \\
\hline Shallow/irregular breathing & $30(5 \%)$ & $12(13 \%)$ & $18(3 \%)$ & $0.00001^{*}$ & $\begin{array}{c}4.41 \\
(2.04-9,49)\end{array}$ \\
\hline Hypoxia symptoms & $14(2 \%)$ & $5(5 \%)$ & $9(2 \%)$ & $0.0207^{*}$ & $\begin{array}{c}3.43 \\
(1.12-10.48)\end{array}$ \\
\hline $\begin{array}{l}\text { Increased work of accessory } \\
\text { muscles of respiratory system }\end{array}$ & $36(6 \%)$ & $12(13 \%)$ & $24(4 \%)$ & $0.0009 *$ & $\begin{array}{c}3.27 \\
(1.57-6.790 \\
\end{array}$ \\
\hline Tachypnoea & $62(10 \%)$ & $24(26 \%)$ & $38(7 \%)$ & $0.00001^{*}$ & $\begin{array}{c}4.73 \\
(2.67-8.38)\end{array}$ \\
\hline Stridor & $14(2 \%)$ & $4(4 \%)$ & $10(2 \%)$ & 0.1275 & - \\
\hline $\begin{array}{l}\text { Reduced vesicular breath } \\
\text { sound }\end{array}$ & $40(6 \%)$ & $23(25 \%)$ & $17(3 \%)$ & $0.00001^{*}$ & $\begin{array}{c}10.41 \\
(5.29-20.46)\end{array}$ \\
\hline Wheezing & $52(8 \%)$ & $9(10 \%)$ & $43(8 \%)$ & 0.5363 & - \\
\hline Pleural friction & $6(1 \%)$ & $0(0 \%)$ & $6(1 \%)$ & 0.3123 & - \\
\hline $\begin{array}{l}\text { Pathological bronchial breath } \\
\text { sound }\end{array}$ & $19(3 \%)$ & $9(10 \%)$ & $10(2 \%)$ & 0.1275 & - \\
\hline Dry rales & $88(14 \%)$ & $11(12 \%)$ & $77(14 \%)$ & 0.5802 & - \\
\hline Crackles & $24(4 \%)$ & $6(7 \%)$ & $18(3 \%)$ & 0.1326 & - \\
\hline \multicolumn{4}{|c|}{ Comorbidities } & $p$ & OR (CI) \\
\hline Ankylosing spondylitis & $4(0.6 \%)$ & $0(0 \%)$ & $4(1 \%)$ & 0.4102 & - \\
\hline Gout & $75(12 \%)$ & $15(16 \%)$ & $60(11 \%)$ & 0.1429 & - \\
\hline Hypertension & $249(39 \%)$ & $29(32 \%)$ & $220(41 \%)$ & 0.1092 & - \\
\hline Obesity & $174(28 \%)$ & $31(34 \%)$ & $143(26 \%)$ & 0.1342 & - \\
\hline Arrhythmia & $55(9 \%)$ & $12(13 \%)$ & $43(8 \%)$ & 0.1022 & - \\
\hline Heart failure & $30(5 \%)$ & $4(4 \%)$ & $26(5 \%)$ & 0.8620 & - \\
\hline Chronic coronary heart disease & $28(4 \%)$ & $5(5 \%)$ & $23(4 \%)$ & 0.5966 & - \\
\hline Heart defects & $17(3 \%)$ & $0(0 \%)$ & $17(3 \%)$ & 0.0862 & - \\
\hline Stroke in medical history & $13(2 \%)$ & $4(4 \%)$ & $9(2 \%)$ & 0.0900 & - \\
\hline IGT & $27(4 \%)$ & $8(10 \%)$ & $19(4 \%)$ & $0.0199^{*}$ & $\begin{array}{c}2.64 \\
(1.21-6.23) \\
\end{array}$ \\
\hline Diabetes & $73(12 \%)$ & $8(9 \%)$ & $65(12 \%)$ & 0.3705 & - \\
\hline Mental illnesses & $109(17 \%)$ & $9(10 \%)$ & $100(18 \%)$ & $0.0440^{*}$ & \\
\hline Mental retardation & $5(1 \%)$ & $0(0 \%)$ & $5(1 \%)$ & 0.3568 & - \\
\hline Thyroid diseases & $70(11 \%)$ & $11(12 \%)$ & $59(11 \%)$ & 0.7440 & - \\
\hline
\end{tabular}




\begin{tabular}{|c|c|c|c|c|c|}
\hline Liver diseases & $25(4 \%)$ & $8(9 \%)$ & $17(3 \%)$ & $0.0107^{*}$ & $\begin{array}{c}2.97 \\
(1.24-7.09)\end{array}$ \\
\hline Hypercholesterolaemia & $171(27 \%)$ & $26(28 \%)$ & $145(27)$ & 0.7328 & - \\
\hline Malignant neoplasms & $32(5 \%)$ & $5(5 \%)$ & $27(5 \%)$ & 0.8423 & - \\
\hline Chronic laryngitis & $14(2 \%)$ & $2(2 \%)$ & $12(2 \%)$ & 0.9883 & - \\
\hline Chronic bronchitis & $29(5 \%)$ & $6(7 \%)$ & $23(4 \%)$ & 0.3253 & - \\
\hline Chronic sinusitis & $23(4 \%)$ & $3(3 \%)$ & $20(4 \%)$ & 0.8480 & - \\
\hline Bronchial asthma & $44(7 \%)$ & $3(3.2 \%)$ & $41(8 \%)$ & 0.1366 & - \\
\hline COPD & $51(8 \%)$ & $10(11 \%)$ & $41(8 \%)$ & 0.2715 & - \\
\hline Interstitial lung diseases & $5(1 \%)$ & $1(1 \%)$ & $4(1 \%)$ & 0.7215 & - \\
\hline Allergic rhinitis & $16(3 \%)$ & $2(2 \%)$ & $14(3 \%)$ & 0.8246 & - \\
\hline Chronic tonsillitis & $36(6 \%)$ & $3(3 \%)$ & $33(6 \%)$ & 0.2843 & - \\
\hline Spine diseases & $212(34 \%)$ & $38(42 \%)$ & $174(32 \%)$ & 0.0745 & - \\
\hline Epilepsy & $14(2 \%)$ & $0(0 \%)$ & $14(3 \%)$ & 0.1204 & - \\
\hline Alzheimer's disease & $2(0.3 \%)$ & $1(1 \%)$ & $1(0.2 \%)$ & 0.1514 & - \\
\hline Gingivitis / dental & $45(7 \%)$ & $13(14 \%)$ & $32(6 \%)$ & $0.0042 *$ & $\begin{array}{c}2.65 \\
(1.33-5.26)\end{array}$ \\
\hline Dizziness & $44(7 \%)$ & $12(13 \%)$ & $32(6 \%)$ & $0.0119^{*}$ & $\begin{array}{c}2.41 \\
(1.19-4.88)\end{array}$ \\
\hline Peripheral joint diseases & $76(12 \%)$ & $15(16 \%)$ & $61(11 \%)$ & 0.1596 & - \\
\hline Muscle diseases & $74(12 \%)$ & $18(20 \%)$ & $56(10 \%)$ & $0.0099 *$ & $\begin{array}{c}2.13 \\
(1.19-3.83) \\
\end{array}$ \\
\hline Chronic gastritis & $90(14 \%)$ & $22(24 \%)$ & $68(13 \%)$ & $0.0035^{*}$ & $\begin{array}{c}2.21 \\
(1.29-3.81)\end{array}$ \\
\hline Chronic enteritis & $46(7 \%)$ & $9(10 \%)$ & $37(7 \%)$ & 0.2217 & - \\
\hline Vascular aneurysm & $4(1 \%)$ & $2(2 \%)$ & $2(0.3 \%)$ & $0.0422 *$ & $\begin{array}{c}6.05 \\
(0.84-43.47) \\
\end{array}$ \\
\hline Anemia & $18(3 \%)$ & $5(6 \%)$ & $13(2 \%)$ & 0.1017 & - \\
\hline Renal failure & $14(2 \%)$ & $3(3 \%)$ & $11(2 \%)$ & 0.4504 & - \\
\hline $\begin{array}{l}\text { Diseases of the veins of the } \\
\text { lower extremities }\end{array}$ & $52(8 \%)$ & $9(10 \%)$ & $43(8 \%)$ & 0.5363 & - \\
\hline Systemic lupus & $6(1 \%)$ & $3(3 \%)$ & $3(1 \%)$ & $0.0127^{*}$ & $\begin{array}{c}6.1 \\
(1.21-30.72)\end{array}$ \\
\hline RA & $12(2 \%)$ & $1(1 \%)$ & $11(2 \%)$ & 0.5444 & - \\
\hline Atherosclerosis & $27(4 \%)$ & $12(13 \%)$ & $15(3 \%)$ & $0.00001^{*}$ & $\begin{array}{c}5.32 \\
(2.40-11.77) \\
\end{array}$ \\
\hline Migraine & $39(6 \%)$ & $11(12 \%)$ & $28(5 \%)$ & $0,0114^{*}$ & $\begin{array}{c}2.51 \\
(1.20-5.25)\end{array}$ \\
\hline
\end{tabular}

IQR - interquartile range, ${ }^{*} \mathrm{p}<0.05$, OR - odds ratio, CI - confidence interval,

GCS - glucocorticosteroids, NSAID - nonsteroidal antiinflammatory drugs, IGT- impaired glucose tolerance,

COPD - chronic obstructive pulmonary disease, RA - reumathoid arthritis

Table II. Multivariate analysis of clinical parameters

Tabela II. Analiza wieloczynnikowa parametrów klinicznych

\begin{tabular}{|c|c|c|}
\hline Clinical parameter & OR & CI \\
\hline Duration of fever (days) & 3.15 & $2.04-4.85$ \\
\hline Muscle aches & 1167.62 & $182.01-7490.53$ \\
\hline Tachycardia & 4.18 & $1.36-12.86$ \\
\hline Atherosclerosis & 12.60 & $1.31-121.31$ \\
\hline
\end{tabular}

CI - confidence interval, OR - odds ratio 
Based on the regression analysis, it was found that the diagnosis of influenza in patients with symptoms of respiratory infection becomes more likely with a prolonged fever, and with the development of muscle pain and tachycardia (Table II). However, among comorbidities, atherosclerosis should be considered a risk factor.

\section{DISCUSSION}

According to published data, viral infections, including influenza, are one of the most common reasons for patients visiting a GP surgery (17), accounting for a total of $63 \%$ of the causes of infectious symptoms in patients in the quoted publication. Apart from the influenza virus, which in the cited analysis accounted for $24 \%$ of the causes of infection, rhinoviruses are also a common cause, accounting for $33 \%$ of the identified causes of infectious symptoms. In this study, the bacterium Streptococcus pneumoniae was confirmed as the etiological factor in one in five patients. In the presented analysis of adult patients, the presence of the influenza virus was confirmed in $14 \%$ of the studied patients. Verification was performed with a rapid antigen test with a sensitivity of $90 \%$ and a specificity of $99 \%$ (for Influenza A type), which has a limited value in relation to the PCR test (sensitivity and specificity would be appropriate, respectively), hence the possibility of underestimating the occurrence of all cases of influenza may be suspected. According to the clinical criteria, $56 \%$ of all patients were qualified for a rapid antigen test to be performed. Of this group, one in four patients had a positive antigen test result. However, this confirms the importance of the influenza virus as one of the most common etiological causes of infections identified in primary care.

According to the literature, the typical symptoms of influenza include: cough, sudden fever $>38^{\circ} \mathrm{C}$, rhinitis, muscle pain (18), which is consistent with the results of this analysis, in which statistically significantly more frequent occurrence of the above symptoms was observed in patients with diagnosed influenza than in patients with other respiratory infections of probably different etiology. Presence of high fever, muscle pain and tachycardia were found factors increasing the probability of influenza diagnosis.

According to published data, pneumonia and bronchitis, secondary bacterial infections of the lower respiratory tract, otitis media, myocarditis and pericarditis, and neurological symptoms are among the most common post-influenza consequences (1921). In children, the most common complications are subglottic laryngitis and otitis media (22). The presented analysis, taking into account adult patients, showed similar results - pneumonia and bronchitis
Leczenie zakażenia wirusem grypy oseltamiwirem zastosowano u chorych z czynnikami ryzyka ciężkiego przebiegu grypy, w przypadkach możliwości rozpoczęcia leczenia do 48 godzin od wystąpienia pierwszych objawów $(15,16)$ chorych dorosłych z ciężkim, powikłanym lub postępującym przebiegiem grypy - ogółem w $76 \%$ przypadków (70 p.)

GKS (glikokortykosteroidy) włączono u 6 pacjentów - 2 pacjentów z zaostrzeniem przewlekłego zapalenia oskrzeli, 1 pacjenta $\mathrm{z}$ astmą oskrzelową, 1 pacjenta z POChP (przewlekłą obturacyjną chorobą płuc), 2 pacjentów z zapaleniem płuc. GKS zastosowano w postaci nebulizacji u 3 pacjentów, w postaci aerozolu proszkowego u 1 pacjenta, w postaci doustnej u 2 pacjentów.

$\mathrm{Na}$ podstawie analizy regresji stwierdzono, że rozpoznanie grypy u pacjenta $\mathrm{z}$ objawami infekcji dróg oddechowych staje się bardziej prawdopodobne przy dłużej trwającej gorączce, oraz w przypadku wystąpienia bólu mięśni i tachykardii (Tab. II). Natomiast wśród chorób współwystępujących za czynnik ryzyka należy uznać miażdżycę.

\section{DYSKUSJA}

Wg danych $\mathrm{z}$ piśmiennictwa infekcje wirusowe, w tym grypa są jedną z najczęstszych przyczyn wizyt pacjentów w poradni lekarza rodzinnego (17) stanowiąc łącznie $63 \%$ przyczyn objawów infekcyjnych u pacjentów w cytowanej publikacji. Poza wirusem grypy, który w cytowanej analizie stanowił $24 \%$ przyczyn infekcji, równie częstą przyczyną były rinowirusy, stanowiąc $33 \%$ zidentyfikowanych przyczyn objawów infekcyjnych. W pracy Creer i wsp. u co piątego pacjenta potwierdzano Streptococcus pneumoniae jako czynnik etiologiczny. W przedstawionej obecnie analizie dorosłych pacjentów obecność wirusa grypy potwierdzono u $14 \%$ badanych. Weryfikacji dokonano szybkim testem antygenowym o czułości 90\% i specyficzności 99\% (dla grypy A), który ma ograniczoną wartość w stosunku do badania PCR, stąd można podejrzewać możliwość niedoszacowania wystąpienia wszystkich przypadków grypy. Według kryteriów klinicznych do wykonania szybkiego testu antygenowego zakwalifikowano $56 \%$ ogółu pacjentów. $Z$ tej grupy u co czwartego pacjenta wynik testu antygenowego w kierunku grypy był pozytywny. Potwierdza to znaczenie wirusa grypy jako jednej z częstszych przyczyn etiologicznych infekcji rozpoznawanych w podstawowej opiece zdrowotnej.

Według piśmiennictwa do typowych objawów grypy należą: kaszel, nagła gorączka $>38^{\circ} \mathrm{C}$, nieżyt nosa, ból mięśni (18). Powyższe obserwacje pokrywają się z wynikami obecnej analizy, w której zaobserwowano istotnie statystycznie częstsze występowanie powyższych objawów u pacjentów z rozpoznaną grypą niż w przypadku pozostałych infekcji dróg oddechowych 
were the most common complications of influenza. In one case there was a cardiac complication in the form of myocarditis. Overall, the symptoms of otitis media were diagnosed in one in ten patients - most of them did not require antibiotic therapy. Complications in the form of possible secondary bacterial superinfection of the upper respiratory tract were diagnosed in one in 20 patients - acute sinusitis and acute otitis media, for which antibiotic therapy was administered.

Some sources state that the coexistence of influenza with bacterial superinfection occurs in only $0.5 \%$ of influenza cases in young, healthy people, in $2.5 \%$ of influenza in elderly people with risk factors for influenza complications, and up to $34 \%$ of people requiring intensive medical care (23). On the other hand, the authors emphasize that in their opinion, prophylactic antibiotic therapy is justified in populations with a higher risk of influenza-related complications, as it may improve the prognosis, morbidity and mortality and may contribute to reducing the length of hospital stay, as well as reducing influenza-related public health costs. The use of antibiotics in the current study was $19 \%$ in the group of patients diagnosed with influenza, $46 \%$ in the case of other infections. This quite frequent use of antibiotics occurred most often in the case of clinical suspicion of bacterial superinfection, less frequently in the case of suspected primary bacterial infection and due to the diagnostic and time-limited possibilities of verifying the etiology of infections in the primary care.

In the presented analysis, patients with impaired glucose tolerance and diabetes comprised a fairly large group of patients diagnosed with influenza. Published reports confirm an increased risk of infections, both bacterial and viral, in these patients (24). Research shows that diabetic patients are at increased risk of lower respiratory tract infections, urinary tract infections, and infections of the skin and mucous membranes.

The results of our study showed more frequent occurrence of atherosclerosis in patients with diagnosed influenza than in other infections classified as non-influenza. The authors dealing with this issue emphasize the importance of the state of impaired immune balance and the dysregulation of cytokine release, as well as the permanent intravascular inflammation in patients with atherosclerosis. It can be concluded that in this group of patients, influenza has a more symptomatic course, which could have contributed to greater reporting of these patients to the GPs (25).

In the group presented in this analysis, a total of $5.8 \%$ of patients were vaccinated (37/631), while among patients with influenza only one person was vaccinated ( $1 \%$ of patients), which confirms the low o prawdopodobnie innej etiologii. Wykazano, że objawy w postaci gorączki, bólu mięśni oraz tachykardii zwiększają prawdopodobieństwo wystąpienia grypy u pacjenta.

Według danych z piśmiennictwa do najczęściej występujących powikłań pogrypowych należą zapalenie płuc i oskrzeli, wtórne infekcje bakteryjne dolnych dróg oddechowych, zapalenie ucha środkowego, zapalenie mięśnia sercowego i osierdzia, powikłania neurologiczne (19-21). U dzieci najczęstszymi powikłaniami są podgłośniowe zapalenie krtani i zapalenie ucha środkowego (22). W przedstawionej analizie biorącej pod uwagę pacjentów dorosłych wykazano podobne wyniki - zapalenie płuc i oskrzeli były najczęstszym powikłaniem grypy. W pojedynczym przypadku doszło do powikłania kardiologicznego w postaci zapalenia mięśnia sercowego. Ogółem objawy zapalenia ucha środkowego rozpoznano u co 10 pacjenta - większość z nich nie wymagała $\mathrm{z}$ tego powodu antybiotykoterapii. U co 20 pacjenta rozpoznano powikłania w postaci prawdopodobnego wtórnego nadkażenia bakteryjnego górnych dróg oddechowych - ostre zapalenie zatok oraz ostre zapalenie ucha środkowego, z powodu których zastosowano antybiotykoterapię.

Niektóre źródła podają, że współwystępowanie grypy $\mathrm{z}$ nadkażeniem bakteryjnym występuje tylko w $0,5 \%$ przypadków grypy u młodych, zdrowych osób, w 2,5\% grypy u osób starszych z czynnikami ryzyka powikłań pogrypowych oraz aż do $34 \%$ osób wymagających intensywnej opieki medycznej (23). Z drugiej strony autorzy podkreślają, że $\mathrm{w}$ ich przekonaniu uzasadnione jest zastosowanie profilaktyczne antybiotykoterapii w przypadku populacji o wyższym ryzyku powikłań, gdyż może poprawić rokowanie oraz zachorowalność i śmiertelność związaną z grypą i może przyczynić się do skrócenia czasu pobytu w szpitalu z powodu grypy, a także obniżenia kosztów zdrowia publicznego związanych $\mathrm{z}$ tą chorobą. W niniejszej pracy antybiotyki zastosowano u 19\% pacjentów z rozpoznaną grypą, w przypadku pozostałych infekcji $46 \%$ pacjentów. Dość częste zastosowanie antybiotyku miało miejsce zwykle w sytuacji klinicznego podejrzenia nadkażenia bakteryjnego infekcji wirusowych, rzadziej w przypadku podejrzenia pierwotnej infekcji bakteryjnej oraz z powodu ograniczonych diagnostycznie i czasowo możliwości weryfikacji etiologii zakażeń w podstawowej opiece zdrowotnej.

$\mathrm{W}$ przedstawionej analizie pacjenci z zaburzeniem tolerancji glukozy i cukrzycą stanowili dość liczną grupę pacjentów z rozpoznaniem grypy. Piśmiennictwo potwierdza zwiększone ryzyko infekcji - zarówno bakteryjnych, jak i wirusowych u tych pacjentów (24). Badania pokazują, że pacjenci z cukrzycą są narażeni na zwiększone ryzyko infekcji dolnych dróg oddecho- 
level of vaccination of patients in Poland. According to WHO recommendations, flu vaccination among seniors $65+$ should be implemented at the level of $75 \%$ of the vaccination status. The level of influenza vaccination in the $65+$ age group in the EU countries is on average approx. $47 \%$. There are clear differences in individual countries - from $75 \%$ in the United Kingdom to $44 \%$ in Denmark, or less than $10 \%$ in Poland (15). Moreover, studies show that influenza vaccination is effective not only in preventing influenza, but also in its complications, e.g. otitis media in children (26). Multicentre meta-analyzes involving elderly patients clearly show that immunization against influenza is accompanied by a significant reduction in respiratory diseases, pneumonia, hospitalization and mortality compared to unvaccinated people (27).

The effectiveness of immunization in working age adults is estimated at $77 \%$ in influenza prevention. These issues are important both in terms of health and economics. The benefits include shorter periods of absence from work, reduced frequency of medical visits, reduced number of hospital admissions, lower drug consumption, but also lower costs of treating post-influenza complications $(9,19,20)$. It is believed that $70 \%$ of the population must be vaccinated to achieve immunity. The vaccination effectiveness in the elderly is lower than in the young (28).

In Poland, the disturbing phenomenon of extremely low public approval for vaccination against influenza has been observed for a long time. This is illustrated by the data on the vaccination coverage of the entire population at around $4 \%$. This places Poland in one of the last places in Europe in terms of the number of vaccinated persons (29). In the 2019/2020 season, only $4.12 \%$ of Poles were vaccinated against influenza, in the $2018 / 2019$ season $-3.9 \%$.

In the presented group of adult patients, the majority of patients $(76 \%)$ received the neuraminidase inhibitor oseltamivir at the standard dose for five days. Most of these people had an uneventful course of influenza. Recent studies also confirm that both children $\geq 1$ year of age and adults, especially with comorbidities, $\geq 65$ years of age, benefit clinically from a faster recovery after taking oseltamivir in the course of influenza-like illness. Initiation of oseltamivir treatment within 48-72 $\mathrm{h}$ of symptom onset seems to provide similar benefits as that of starting treatment $<48 \mathrm{~h}(30)$.

The limitations of the presented work include, among others, lack of PCR identification in the case of influenza and failure to culture the tonsils in the case of strep throat. Moreover, the study group included adult patients only, without a pediatric group.

Performing study on a large screening group of patients with accompanying various comorbidities who often first see a primary care physician is a strengths wych, infekcji dróg moczowych oraz infekcji skóry i błon śluzowych.

W pracy zaobserwowano częstsze występowanie miażdżycy u pacjentów z rozpoznaną grypą niż w przypadku pozostałych infekcji, zakwalifikowanych jako zakażenia o potencjalnie innej etiologii. Autorzy zajmujący się tym zagadnieniem podkreślają znaczenie stanu zaburzonej równowagi immunologicznej i dysregulacji uwalniania cytokin oraz permanentny stan zapalny wewnątrznaczyniowy u pacjentów z miażdżycą. Można wysunąć wniosek, że w tej grupie chorych grypa ma przebieg bardziej objawowy co mogło przyczynić się do większej zgłaszalności tych pacjentów do gabinetu lekarza rodzinnego (25).

$\mathrm{W}$ przedstawionej $\mathrm{w}$ niniejszej analizie grupie zaszczepionych przeciwko grypie zostało ogółem 5,8\% pacjentów (37/631). Natomiast wśród pacjentów, którzy zachorowali na grypę, tylko jedna osoba była zaszczepiona (1\%), co potwierdza niski poziom zaszczepienia przeciw grypie w Polsce. Według zaleceń WHO szczepienia przeciw grypie wśród seniorów $65+$ powinny być realizowane na poziomie $75 \%$ populacji. Poziom zaszczepienia przeciw grypie $\mathrm{w}$ grupie $65+\mathrm{w}$ krajach UE wynosi średnio ok. 47\%. W poszczególnych krajach widać wyraźne różnice - od 75\% w Wielkiej Brytanii do $44 \%$ w Danii i poniżej 10\% w Polsce (15). Ponadto badania pokazują, że szczepienia przeciw grypie są skuteczne nie tylko w zapobieganiu samej chorobie, ale także jej powikłaniom np. zapaleniu ucha środkowego u dzieci (26). Wieloośrodkowe metaanalizy obejmujące starszych pacjentów jednoznacznie pokazują, że immunizacji przeciw grypie towarzyszy istotna redukcja przypadków chorób układu oddechowego, zapalenia płuc, hospitalizacji i umieralności w porównaniu do osób nie zaszczepionych (27).

Skuteczność immunizacji w zapobieganiu grypie u osób dorosłych w wieku aktywności zawodowej szacuje się na $77 \%$. Zagadnienia te są istotne zarówno w aspekcie zdrowotnym jak i ekonomicznym. Korzyści obejmują skrócenie okresu nieobecności w pracy, zmniejszenie częstości wizyt lekarskich, obniżoną liczbę przyjęć do szpitala, mniejsze zużycie leków, ale także niższe koszty leczenia powikłań pogrypowych $(9,19,20)$. Uważa się, że dla uzyskania odporności społeczeństwa konieczne jest szczepienie $70 \%$ populacji. Skuteczność szczepień u osób starszych jest mniejsza niż u osób młodych (28).

W Polsce od dawna obserwuje się niepokojące zjawisko wyjątkowo niskiej aprobaty społeczeństwa dla szczepień przeciw grypie. Ilustrują to dane dotyczące poziomu zaszczepienia całej populacji na poziomie ok. 4\%. Plasuje to Polskę na jednym z ostatnich miejsc w Europie pod względem liczby osób zaszczepionych (29). W sezonie 2019/2020 przeciw grypie zaszczepiło 
of the study, the work reflects the real diagnostic capabilities available to a primary care physician.

\section{CONCLUSIONS}

1. The diagnosis of influenza in patients with symptoms of respiratory infection becomes more likely with prolonged fever, and with the development of muscle pain and tachycardia

2. Influenza was diagnosed mainly in unvaccinated patients.

3. Influenza should be taken into account as an etiological factor of respiratory tract infections in patients visiting their GP, both due to the frequency of occurrence and the possible complicated course.

\section{Conflict Of Interest.}

The authors do not report any financial or personal connections with other persons or organizations that could adversely affect the content of the publication and claim the right to this publication.

\section{REFERENCES}

1. Brydak LB. Grypa - problem stary jak świat. Hygeia Public Health 2012;47(1): 1-7.

2. Influenza (Seasonal). Ask the expert: Influenza Q\&A. http://www.who.int/en/news-room/factsheets/detail/influenza-(seasonal) (date of access: 08/08/2021).

3. Mrukowicz J, Gładysz A, Sawiec P. Grypa. W: Interna Szczeklika: Podręcznik chorób wewnętrznych, Medycyna Praktyczna, Kraków 2012: 2203-2209, http://www.mp.pl/pacjent/ grypa/grypasezonowa/79643, grypa (date of access: 08/08/2021).

4. Czarkowski MP, Niewęgłowska A, SzmulikMisiurek K, et al. Choroby zakaźne i zatrucia w Polsce w 2019 roku. Narodowy Instytut Zdrowia Publicznego - Państwowy Zakład Higieny, Główny Inspektorat Sanitarny $\neg$ Departament Zapobiegania oraz Zwalczania Zakażeń i Chorób Zakaźnych u Ludzi, Warszawa 2020, s. 127

5. Makowiec-Dyrda M, Tomasik T, Windak A, $\mathrm{i}$ in. Zapobieganie, rozpoznawanie i leczenie grypy. Wytyczne Kolegium Lekarzy Rodzinnych w Polsce (2019), Medycyna Praktyczna, Kraków, 2019:7-8. Dostęp: https://www.klrwp. $\mathrm{pl} / \mathrm{strona} / 616 / z a p o b i e g a n i e-r o z p o z n a w a n i e-i-$ leczenie-grypy-2019/pl

6. Brydak LB. Grypa i jej profilaktyka, Springer PWN, Warszawa 1998: 1-216.

7. Goka E, Vallely $\mathrm{P}$, Mutton $\mathrm{K}$, et al. Influenza A viruses dual and multiple infections with other respiratory viruses and risk of hospitalisation się zaledwie 4,12\% Polaków, w sezonie 2018/2019 $3,9 \%$.

W przedstawionej grupie pacjentów dorosłych większość pacjentów (76\%) otrzymała inhibitor neuraminidazy - oseltamiwir w standardowej dawce przez 5 dni. U większości z tych osób przebieg grypy był niepowikłany. Najnowsze badania potwierdzają też, że zarówno dzieci $\geq 1$. roku życia, jak i dorośli, zwłaszcza $\mathrm{z}$ chorobami współistniejącymi w wieku $\geq 65$ lat odnoszą korzyści kliniczne $\mathrm{w}$ postaci szybszego powrotu do zdrowia po zastosowaniu oseltamiwiru w przebiegu choroby grypopodobnej. Rozpoczęcie leczenia oseltamiwirem w ciągu 48-72 h od wystąpienia objawów wydaje się przynosić podobne korzyści jak rozpoczęcie leczenia $<48 \mathrm{~h}(30)$.

Do ograniczeń przedstawionej pracy należy m.in. brak identyfikacji PCR w przypadku grypy oraz niewykonywanie posiewów z migdałków w przypadku anginy. Ponadto $\mathrm{w}$ badanej grupie obecni byli jedynie dorośli pacjenci bez grupy pediatrycznej.

Wykonanie pracy na dużej przesiewowej grupie pacjentów z towarzyszącymi różnymi chorobami współtowarzyszącymi trafiającymi w pierwszej kolejności do lekarza POZ stanowi o jej wartości, praca odzwierciedla realne możliwości diagnostyczne dostępne dla lekarza w POZ.

\section{WNIOSKI}

1. Rozpoznanie grypy u pacjentów z objawami infekcji dróg oddechowych staje się bardziej prawdopodobne przy dłużej trwającej gorączce oraz w przypadku wystąpienia bólu mięśni i tachykardii

2. Grypę rozpoznawano głównie u pacjentów niezaszczepionych

3. Grypa powinna być brana pod uwagę jako czynnik etiologiczny infekcji dróg oddechowych pacjentów zgłaszających się do lekarza rodzinnego zarówno ze względu na częstość występowania jak i możliwy powikłany przebieg

\section{Konflikt interesów.}

Autorzy nie zgłaszają żadnych finansowych ani osobistych powiązań z innymi osobami lub organizacjami, które mogłyby negatywnie wpłynąć na treść publikacji oraz rościć sobie prawo do tej publikacji.

and mortality. Influenza Other Respir Viruses 2013;7(6):1079-87.

8. WHO launches new global influenza strategy. https://www.who.int/news/item/11-03-2019-wholaunches-new-global-influenza-strategy (date of access: 08/08/2021). 
9. Preaud E, Durand L, Macabeo B, et al. Vaccines Europe influenza working group. Annual public health and economic benefits of seasonal influenza vaccination: a European estimate. BMC Public Health 2014;14:813.

10. Woźniak-Kosek A, Kempińska-Mirosławska B, Hoser G. Detection of the influenza virus yesterday and now. Acta Biochim Pol 2014;61(3):465-70.

11. Fiore AE, Fry A, Shay D, et al. Antiviral agents for the treatment and chemoprophylaxis of influenza - recommendations of the Advisory Committee on Immunization Practices (ACIP). MMWR Recomm Rep 2011;60(1):1-24.

12. Ryu SW, Suh IB, Ryu SM, et al. Comparison of three rapid influenza diagnostic tests with digital readout systems and one conventional rapid influenza diagnostic test, J Clin Lab Anal 2018; 32(2):e22234.

13. Miarka M, Horban A, Maliszewska $H$, i in. A clinical utility of a strip test for influenza A/B and comparison with detection by RT PCR. Acta Biochim Pol 2014; 61(3):485-7

14. Szczeklik W. Interna Szczeklika 2020, Medycyna Praktyczna, Kraków, 2020, 626-633.

15. European Centre for Disease Prevention and Control. Seasonal influenza vaccination and antiviral use in EU/EEA Member States Overview of vaccine recommendations for 20172018 and vaccination coverage rates for 2015-2016 and 2016-2017 influenza seasons. Stockholm: ECDC; 2018. https://www.ecdc.europa.eu/sites/ default/files/documents/seasonal-influenzaantiviral-use-2018.pdf

16. Kuś J, Jankowski M. Pozaszpitalne zapalenie płuc (PZP), Medycyna Praktyczna 2018. https://www. mp.pl/interna/chapter/B16.II.3.11.1. (date of access: 08/08/2021)

17. Creer DD, Dilworth JP, Gillespie SH, et al. Aetiological role of viral and bacterial infections in acute adult lower respiratory tract infection (LRTI) in primary care. Thorax 2006;61:75-79.

18. Shah SC, Rumoro DP, Hallock MM, et al. Clinical predictors for laboratory confirmed influenza infections: exploring case definitions for influenza like illness. Infect Control Hosp Epidemiol 2015;36(3):241-8.

19. Brydak LB. Influenza, a disease of the family. Family Medicine \& Primary Care Review 2011;13,2:281-286.

20. Prevention and control of influenza: recommendations of the Advisory Committee on Immunization Practices (ACIP). MMWR, CDC 2010; 59:1-62.
21. Heinonen S, Silvennoinen H, Lehtinen $\mathrm{P}$ et al. Feasibility of diagnosing influenza within 24 hours of symptom onset in children 1-3 years of age. Eur J Clin Microbiol Infect Dis 2011;30:387-392.

22. Ruf BR, Szucs T. Reducing the Burden of Influenza-Associated Complications with Antiviral Therapy. Infection 2009;37(3):186-196.

23. Levet P, Raoult D, Parola P. Treating influenza with antibiotics. Int J Antimicrob Agents 2017;50(4), 505-506.

24. Muller LMAJ, Gorter KJ, Hak E, et al. Increased Risk of Common Infections in Patients with Type 1 and Type 2 Diabetes Mellitus. Clin Infect Dis 2005;41(3):281-288.

25. Peretz A, Azrad M, Blum A, Influenza virus and Atherosclerosis. QJM: An International Journal of Medicine, 2019;112(10):749-755.

26. Jefferson T, Rivetti A, Di Pietrantonj C, et al. Vaccines for preventing influenza in healthy children, Cochrane Database Syst Rev 2018; 2(2):CD004879.

27. Gross PA, Denning CR, Gaerlan PF, et al. Annual influenza vaccination: immune response in patients over 10 years. Vaccine 1996;14(13):1280-1284.

28. Committee for Proprietary Medicinal Products (CPMP). Note for guidance on harmonisation of requirements for influenza vaccines (CPMP/ BWP/214/96). 1997:20-21.

29. https://szczepienia.pzh.gov.pl/faq/jaki-jestpoziom-zaszczepienia-przeciw-grypie-w- polsce/ (date of access: 15/03/2021)

30. Butler CC, van der Velden AW, Bongard E, et al. Oseltamivir plus usual care versus usual care for influenza-like illness in primary care: an openlabel, pragmatic, randomised cotrolled trial. Lancet 2020;395(10217):42-52

Received: 18.03.2021

Accepted for publication: 16.08.2021

Otrzymano: 18.03.2021 r.

Zaakceptowano do publikacji: 16.08.2021 r.

\section{Address for correspondence:}

Adres do korespondencji:

Aneta Rzepka

Przychodnia Lekarza Podstawowej Opieki Zdrowotnej

Medicus

63-800 Gostyń, ul. Starogostyńska 9

e-mail: rzepkaaneta@hotmail.com

tel. +48 692292076 